\title{
МЕЖДУНАРОДНОМУ СУДУ ООН - ПЯТЬДЕСЯТ ЛЕТ
}

P. А. Т узм ухамедов

В мире нет второй такой зарубежной страны, где бы так чтили память российского императора Петра I. Здесь гордятся тем, что он обучался кораблестроению на голландских верфях.

Сегодня именно в Голландии вновь все чаще упоминают имя императора России, но уже другого - Николая II. Впервые о нем благодарно заговорили в самом начале века как $о 6$ инициаторе проведения Первой Гаагской хонференции по укреплению международного мира и развитию гуманитарного права. Конференция привела к созданию Постоянной палаты третейского суда. Американский магнат Карнеги пожертвовал деньги на строительство для этого первого в истории международного судебно-арбитражного учреждения специального здания.

Походящий на костел Дворец мира закончили уже после смерти благотворителя - в 1911 году. Николай II подарил Палате огромную малахитовую вазу. Недалеко от нее, в одном из холлов, установили и бюст царя. Они до сих пор сохранились во Дворце...

В 1999 году в Гааге соберется Третья Всемирная конференция мира, отмечая 100-летие Первой, созванной по предложению императора России.

Правда, сегодня Палата расположилась лишь в нескольких комнатах на втором этахе. В 1920 году ее потеснила Постоянная палата международного правосудия Лиги Наций, а в 1946 году сменивший ее Международный Суд ООН. Позже х нему пристроили современное двухэтажное здание, невидимое со стороны площади Мира, разбитой перед Дворцом. (Сегодня и эти пристройки вынуждены расширять.)

В 1993 году в той же Гааге обосновался Международный трибунал по военным преступлениям на территории бывшей Югославии. С 1995 года здесь же временно расположился Международный трибунал по Руанде.

Таким образом, Россия может гордитъся тем, что в превращении Гааги накануне второго тысячелетия в столицу международного правосудия есть и ее заслуга столетней давности.

* Доктор юридических наук, профессор, председатель Комитета международного права Всемирного федералистского движения, вицс-президент этого движения. 
Однако трудно отделаться от сожаления. Советская, а затем российская дипломатия последних лет иногда оказывается пассивной. Так, идея отметить столетие "гаагской” инициативы России приналлехала не Москве, а министрам иностранных дел стран Движения неприсоединения, выдвинувших ее на своей встрече в Гааге в 1989 году и предложивших предварить Третью конференцию 1999 года Декадой международного права ООН. Не прибыл представитель МИд России и на торжества по случаю 50-летия Международного Суда ООН и не участвовал в специальном мехдународном коллоквиуме, организованном по этому случаю, хотя крут участников был ограниченным и приглашались они персонально.

Коллоквиум по теме "Повышение эффективности Суда" был созван совместно Международным Судом ООН и ЮНКТАР. Прошел он во Дворце мира 16-17 апреля и 18 апреля завершился торжественным заседанием Совета с участием королевы Нидерландов и дипломатического корпуса. На него было приглашено и прибыло около 80 экспертов, юристов-международников и руководителей правовых подразделений внешнеполитических ведомств из более чем 40 стран со всех континентов мира.

Радостной была встреча автора этих строк с судьей Международного Суда ООН профессором Владленом Верещетиным и прибывшим из Лондона за рулем собственного автомобиля Рейном Мюллерсоном с супругой. Оба пользовались большим увахением участников коллоквиума. Сфотографировались втроем на память. Оба просили передать наилучшие пожелания читателям МЖМП, который чтут как одно из лучших международно-правовых периодических изданий в мире.

Коллоквиум был очень интересен. Формулируя его цели в пленарном докладе, Председатель Суда Мухаммад Бедхауи свел их $\mathbf{x}$ двум: с одной стороны, “выделить наиболее существенные черты Суда", а с другой - обсудить будущее Суда, выявив то, в чем ему следует "организационно и функционально адаптироваться и модифицироваться".

В рамках этих целей было выделено 13 тем, каждая из которых составила предмет работы двух параллельно функционировавших секций. Председателем дискуссии по каждой темс был один из членов Суда. Российский судья профессор В.С. Верещетин председательствовал при обсуждении темы "Космическое право как новая область международного права для деятельнос:т Суда".

Темы можно ббъединить в две группы:

1. Роль и значение Суда в международных отношениях как "главного юридичесхого органа ООН" - формула, на которой сходились все участники (расширение пользования Судом, укрепление роли Суда в рамках $О О \mathrm{H}$, соотношение компетенций Суда с иными 
международными судебными органами, пути будущего развития Суда).

2. Организация работы Суда (повышение эффективности его работы, процедура подготовки дел, методы избрания судей, функционирование и управление делами Суда, роль судей ad hoc, учет новых отраслей международного права, последствия постановлений Суда).

В обеих секциях дискуссии прошли активно. К сожалению, официальные докладчики и специально назначенные комментаторы докладов забирали большую часть времени, оставляя другим участникам возможность лишь для нескольких кратких вопросоввыступлений. Тем не менее, как мне думается, было поставлено и обсуждено немало животрепешуших проблем.

Международного права непосредственно касались дискуссии по первой группе тем, о них и хочу рассказать. Но прежде - несколько слов о некоторых итогах полувековой работы Суда.

За 50 лет Суд вынес 60 постановлений по делам, которые он принял к рассмотрению, и дал 21 консультативное заключение. $\mathrm{K}$ моменту проведения коллоквиума на его рассмотрении было еще 8 дел (среди них и такое, как "Применение Конвенции о предупреждении и нахазании преступления геноцида"), а также несколько запросов о консультативных заключениях (включая запрос ВО3 и Генеральной Ассамблеи ООН "О правомерности использования ядерного оружия"). Обязательную юрисдикцию Суда, впрочем с многочисленными оговорками, признали 59 государств. Кстати, США, отозвавшие в 1985 году свое заявление в связи с иском Никарагуа, уже через два года обратились в Суд с жалобой против Италии, хотя прошлой безоговорочной формулы признания юрисдикции пока не восстановили. Как сообщил в своем докладе Председатель Суда, судебная обязательная юрисдикция, кроме того, $\mathrm{k}$ 1996 году включена в более чем 270 много- и двусторонних договоров.

Вместе с тем он не мог не отметить “относительный недостаток энтузиазма" государств в отношении признания юрисдикции Суда. По мнению Председателя Суда, тому есть объянения. Кроме понятных политических интересов суверенных государств он выделил следующие два постоянных фактора. Первый - послевоенное давление холодной войны и связанный с ней "климат напряженности, неопределенности и подозрительности”. Второй - время финансовых затрат, связанных с разбирательством в Суде. Хотя для членов ООН процедура судопроизводства бесплатна, обратившееся в Суд государство несет немалые дополнительные расходы. Это не раз вызывало недовольство, особенно развивающихся стран. Как известно, именно пюэтому Генеральный секретарь ООН в ноябре 
1989 года учредил “Фонд помоши государствам в разрешении споров через Международный Суд ООН".

K числу факторов, снижающих эффективность деятельности Суда, следует, видимо, отнести и то, что Председатель назвал “одним из наиболее беспокояших обстоятельств". Он имел в виду неуклонное возрастание числа различных форм особого мнения членов Суда. "Обретая нежелательные пропорции, такая практика наносит ущерб авторитету Суда”, - сказал он.

Соглашаясь с Председателем, не могу, однако, не отметить, что подобное явление - результат воздействия на работу Суда окончания холодной войны. В итоге, как мне кажется, деятельность Суда становится менее политизированной, что было весьма заметно в период холодной войны. Правда, было и сохраняется, по-моему, и желание отдельных судей “прозвучать”, “войти в историю”, высказав свое несогласие с остальными.

Одним из основных среди обсухдавшихся в рамках дискуссий по темам первой группы был вопрос о компетенции и юрисдикции Суда. Прежде всего - о круге субъектов (сторон), могуших пользоваться услугами Суда. Согласно его Статуту, как известно, это только государства и только правовые споры между ними. Кроме того, юрисдикция Суда различается согласно двум сферам его компетенции рассмотрение споров и дача консультативных заключений. Во втором случае изначально субъектом была только Генеральная Ассамблея.

За 50 лет здесь уже ироизошли подвижки. За разрешением споров сегодня в Суд могут обрашаться не только государства, но и такое межгосударственное объединение, как ООН. За консультативным заключением могут обрашаться и Совет Безопасности, и ЭКОСОС, а также специализированные учреждения ООН.

Позиция консервативного крыла Суда по этому вопросу нашла отражение в докладе Председателя Суда, когда он заявил о нежелательности расширения круга субъектов по спорам за счет других образований, кроме межгосударственных организаций, а по консультативным заключениям - других органов и других ММПО. В качестве примеров были приведены: в первом случае - Генеральный секретарь ООН, во втором - региональные организации. Честно скажу, такое откровенное противостояние меня удивило. Известно, что Бутрос Гали не раз поднимал вопрос о том, чтобы Генеральному секретарю ООН также было предоставлено право на запрос консультативного заключения, хотя бы в вопрогах руководимых им миротворческих усилий. Это его право на коллоквиуме отстаивал и представитель Правового департамента Секретариата ООН. Он нашел поддержку у ряда выступающих.

Один из участников предложил изыскать выход в тсі, чтобы заключить многостороннюю конвенцию, оговорив право ее учас- 
тников обращаться в Суд за консультативным заключением. Были и более радикальные предложения. Одна из дам-“комментаторов” настаивала на том, чтобы не только правом на консультативное заключение, но и на то, чтобы быть стороной в спорах перед Судом, пользовались и "негосударственные образования, такие как неправительственные организации, группы и индивиды”. Соглашаясь с ней, другой участник сказал, что таким правом должны пользоваться по крайней мере народы. Он отметил явный диссонанс мехду позицией $\mathrm{OOH}$, созданной от имени народов, утвердившей в качестве одного из основных принципов современного международного права принцип равноправия и самоопределения народов и решающим ббразом содействующей. закреплению иных прав народов, и позицией Суда, который, будучи органом ООН, не идет, однако, далее подтверждения права народов на самоопределение в качестве одного из основных принципов международного права, как это последний раз было в связи с делом о Восточном Тиморе (1995 г.). Он обратил внимание участников на то, что в процессе демократического реформирования на рубеже XXI века в ее структуре могут появиться органы, прямо представляющие народы. Так, Всемирное федералистское движение и ряд других НПО, имеющих статус при ООН, добиваются создания в ООН Парламентской (Народной) ассамблеи, наряду с межгосударственной Генеральной Ассамблеей, а НПО коренных народов предпринимают усилия $\mathbf{k}$ созданию при ООН Форума коренных народов. В таком случае открыто встанет вопрос о равной правосубъектности народов и государств в рамках ООН и, соответственно, в ее Суде.

Уже сегодня народы должны иметь право на запрос консультативного заключения через свои представительные НПО. Ясно, что их ни в коем случае нельзя подгонять под положения сегодняшнего Статута Суда и принуждать искать государство (государства), которое согласилось бы представлять их запрос или иск, как это практически имело место в свое время с колониальной Намибией, интересы которой согласилась представлять Эфиопия.

В рамках проблемы юрисдикции и компетенции Суда некоторые выступавшие подчеркивали, что если 59 заянлений о признании обязательной юрисдикции отражают определенное признание авторитета Суда, то в то же время это и свидетельство известного несовершенства самой концепции обязательной юрисдикции. Та форма, в которой она сейчас существует, вызывая многочисленные оговорки при заявлениях, требует реформаторского подхода, говорили ряд участников.

Другая тема, вызвавшая активную дискуссию, была связана с “пролиферацией” в последние 15-20 лет международных судебноарбитражных органов, помимо Международного Суда ООН. Вопрос 
поднял сам Председатель Суда, заявив, что тахое явление “может поставить проблему координации” юрисдикции таких учреждений. Действительно, сегодня речь идет о ряде существующих и создаваемых таких глобальных органов, ках два трибунала (по преступлениям в бывшей Югославии и Руанде), Третейский суд Международной организации труда, Международный трибунал по морскому праву, Международный уголовный суд и др., а также о следующих региональных учреждениях: Европейский суд по правам человека, Межамериканский суд по правам человека, Центральноамериканский суд, Суд по примирению и арбитраху ОБСЕ, механизм. Организации африканского единства по предупреждению, управлению и урегулированию конфликтов и др.

Положение, таким образом, качественно новое. С одной стороны, резко уменьшается число возможных обрашений в Суд ООН, с другой - возникает вопрос: возможно ли, и если да, то каким должно быть соподчинение этих органов?

На коллоквиуме предлагались различные выходы из ситуации. Председатель в своем докладе высказал предположение, что сложившееся положение поможет Суду освободиться от “определенных частных категорий споров" и сконцентрироваться на "решении других споров, таких, которые посильны ему одному, и на его консультативных функциях". Он отметил также, что, “будучи главным юридическим органом ООН, Суд будет отдавать предпочтение важнейшнм вопросам, возникающим на глобальном уровне".

Однако в ходе дискуссии были высказаны и иные суждения. K примеру, предлагалось восстановить идею о компетенции Суда, выдвигавшуюся, но отвергнутую еще в 1945 году на конференции в Сан-Франциско. Суть ее в том, чтобы Суд занимался лишь толкованием Устава ООН. Говорилось и о том, что другие судебные учреждения могли бы стать своеббразными подготовительно-тренировочными инстанциями, а Суд слал бы своеобразной апелляционной инстанцией. Иные высказывались в пользу установления “юридической иерархии" во главе с Международным Судом как главным юридическим органом ООН.

Оптимальной представляется, однако, следующая точка зрения, также высказанная на колјоквиуме. Каждый судебный орган должен быть самостоятельным в своей области (компетенции). От Международного Суда отошли бы обычные и специальные дела. Подсудными ему стали бы споры по юрисдикциям остальных судов и общие вопросы и дела. Таким образом, как юридическое учреждение Суд стал бы одним из “стоящих над” остальными.

Следует остановиться еще на одной теме, прямо касающейся перспектив развития мехдународного права через деятельность 
Суда. Обобщенно назвал бы ее реформированием состава Суда и выборов судей в него.

Исходя из общей тенденции в ООНовской политике Суда заботиться о собственной автономии среди остальных пяти главных органов ООН, некоторые выдвигали мысль о том, чтобы судьи рекомендовались не национальными группами Постоянной палаты Третейского суда, назначаемыми опять же самими соответствующими государствами и действующими в интересах их правительств.

Выдвигалось и другое предложение, подразумевающее повышение профессионального уровня Суда. Учитывая, что практически в каждом составе Суда представлены пять постоянных членов Совета Безопасности, предлагалось на десять остальных судейских кресел иметь выбор из достаточно широкого круга кандидатов, известных своим авторитетом в области международного права. При этом рекомендовалось увеличить срок их службы либо до 15 лет, либо сделать его похизненным. Идея понятна: хотя сами выборы - процедура политическая, надо использовать ее максимально для повышения профессионализма Суда.

Была высказана и такая мысль. Коль скоро международное право повсеместно проникает в сферу национального права, выбирать в Суд следует экспертов не только в области первой, но и второй отрасли права.

На коллоквиуме, естественно, прозвучала и реакция на известные решения Совета Безопасности ООН 1990-х годов о создании трибуналов по бывшей Югославии и Руанде. Она, как и в дискуссиях по другим темам, была разной. Один из официальных докладчиков утверждал, что в проблемах мира и безопасности Совет Безопасности и Международный Суд как бы дополняют друг друга: Совет занимается политикой, Суд - правом. Другой участник поставил вопрос прямо: "Почему Суд, будучи главным юридическим органом ООН, должен априорно руководствоваться политическими решениями одного из главных органов?" Суд должен иметь право принимать решения о таких постановлениях Совета Безопасности политического свойства, но касающихся международного судопроизводства.

В завершение не могу не изложить пассаж одной из своих бесед с участниками коллоквиума. Судья Абдул Карома - вероятно, самый молодой среди пятнадцати, но с богатым политико-дипломатическим опытом. Известна, например, его весьма полезная деятельность в составе Комитета 24-x по деколонизации. Он единственный, кроме профессора В.С. Верешетина, из членов Суда, читающий по-русски. По его просьбе с удовольствием подарил ему свой “Словарь прав народов”, изданный в Уфе в 1996 году. Согласившись с тем, что там написано о принципе равноправия и само- 
определения народов, он сказал, что в его представлении субъектами прав на самоопределение могут быть не только колониалыные народы, но и все народы вообще. Касаясь актуальной проблемы выполнения государствами их обязательств, связанных с этим правом народов, он сказал: “Мы ранее в Комитете 24-х, а теперь и в Суде сделали все, чтобы подтвердить его в качестве фундаментального принципа международного права. Теперь дело за самими субъектами этого права добиваться его реализации".

В целом же коллоквиум в Гааге показал, что, несмотря на объяснимую и, видимо, неизбежную консервативность любого судебного органа, Мехдународный Суд ООН, с одной стороны, находится под давлением процесса объективных изменений в мире за минувшие полвека, а с другой - в состоянии реагировать на них, адаптироваться и, следовательно, модернизироваться.

Это вселяет надежду на то, что практика и наука будут все чаще получать наиболее авторитетное подтверждение и развитие не только конвенционных основ, но и обычных норм международного права.

Москва - Гаага - Москва, апрель 19962.

\section{ОБСУЖДЕНИЕ IІРОЕКТА УСТАВА МЕЖДУНАРОДНОГО УГОЛОВНОГО СУДА В СПЕЦИАЛЬНОМ КОМИТЕТЕ ГЕНЕРАЛЬНОЙ АССАМБЛЕИ ООН}

В декабре 1996 года исполняется 50 лет с тех пор, как ООН приняла прннципы Нюрнбергского трибунала - прообраза Мөждународного уголовного суда. $И$ хотя он был трибуналом ad hос, төм не менөе его принципы легли в основу всөй послевоенной международной уголовной юстиции. Продолжая эту тему, МЖМП публикует настоящую статью.

История попыток создания постоянного органа международной уголовной юстиции насчитывает уже несколько десятилетий ${ }^{1}$. Впервые Организация Объединенных Наций обратилась $\mathbf{x}$ этой проблеме в 1948 году. Тогда стимулом для этого стало создание Нюрнбергского и Токийского трибуналов. Уже в начале 50-х годов появился первый проект Статута Международного уголовного суда. Однако работа над ним была прервана главным образом по политическим причинам. Поворотным моментом в истории создания постоянного Суда стало учреждение Советом Безопасности 